\title{
Volunteer Movement in Ukraine in the Situation of External Aggression
}

\author{
Oleg Tkach \\ Doctor of Political Science, Professor, Taras Shevchenko National University of Kyiv \\ (Kyiv, Ukraine) \\ E-mail: tio19@ukr.net \\ https://orcid.org/0000-0003-3131-1533
}

\begin{abstract}
Anatoly Tkach
Ph.D. student, Open International University of Human Development "Ukraine"

(Kyiv, Ukraine)

E-mail: tio19@ukr.net

https://orcid.org/0000-0003-3254-8161
\end{abstract}

The paper analyzes volunteering as a factor in the self-organization of society in period Joint Forces Operation, a new social need. It is proved that during the period of democratic transit the volunteer movement became a factor of civic activism. It is emphasized that volunteering has become a political institution of Ukrainian society, an element of the political system. Volunteering contributes to the transformation of civil society. Volunteering acquired the status of a political institution, due to its great importance in political life and significant activity in the political sphere; at present it belongs to social and political movements, which in a certain sense can be considered as groups of political pressure; partnership with the state in solving important matters. A weighty function of volunteering was the compensatory replacement of the state in the logistic support of the front line during the Russian aggression against Ukraine. In volunteer activities, significant financial and material resources were involved, it acquired a mobilization character. The number of volunteers and volunteer organizations has increased many times. Volunteering has become a nationwide cause. Experts in information technology, mechanics, weapons and military equipment specialists are involved in it. The motivation for volunteering has become patriotic, civil and moral.

Keywords: volunteer, volunteering, institutionalization, political institution, social movement, Joint Forces Operation, political transformation, state-society relations, public, volunteering policy, social institute, volunteer's movement

Received: March 23, 2019; accepted: April 19, 2019

Ukrainian Policymaker, Volume 4, 2019: 52-61.

https://doi.org/10.29202/up/4/8

\footnotetext{
(C) Tkach, Oleg, 2019

(C) Tkach, Anatoly, 2019
} 


\section{Introduction}

The relevance of the topic is due to the phenomenon of volunteering in Ukraine. The proclamation of independence of Ukraine gave impetus to the beginning of transformation processes in all spheres of society. The end of the era of collective forms of participation in social and political life, the transformation of the social structure, the reorientation to the foundations of a market economy, social and political instability led to the decline or partial conversion of the old types of social relations and the emergence of new ones as well as new social institutions, one of which is volunteering.

Analysis of present research and publications research problems scientists. Institutions as a part of civil society took the place of one of its main categories. The problematic of voluntary activity is investigated within the framework of three approaches: social (Friedrich Hayek), economic (Lester M. Salamon, Megan A. Haddock, Mishiel de Lange, Angela Ellis Paine, Jakub Dostal, Aleksandra Zavadska, Martin Vavra, Robert Fash) and labor (Kristiane Biedermann, Klaus Shpiler). G. Spencer Monson, Emile Durkheim, Max Weber, Talcott Parsons, Robert K. Merton, Ralf Dahrendorf, Neil J. Smelser, Piter Berger, Tomas Lukman, J. Rodney Turner, Piotr Sztompka, and others researched the theory of social movements and institutions in Western science. In Ukrainian science, Viacheslav Golub, Iryna Bilich, Yaroslava Buzdugan, Olga Vaniushyna, Nataly Ivchenko, Svitlana Sydorenko, Nataly Larionova, Lubov Pesotska, investigated the problems of social institutions and institutions.

\section{The presentation of the primary material}

Volunteering is the foundation of civil society. Without the participation of volunteers, it is difficult to imagine public organizations and charity. Without them, it is impossible to achieve public control over the actions of government and business. Without volunteers there is not enough energy for building a society, there is not enough creative potential to solve social problems. In 2015 , over $62 \%$ of respondents recognized the role of volunteers in political changes in Ukraine [Volunteer, 2016: 5].

In Ukraine, volunteering turns into an influential political institution of the society with all the features and qualities inherent in this element of the political system. It is not only a factor in the self-organization of society, a manifestation of the selfless activity of patriots to support Joint Forces Operation soldiers but also volunteering acts as a new social need. During the period of the anti-terrorist operation, the volunteer movement turned into a significant factor in civic activism. Due to volunteering, civil society was transformed in Ukraine [Kornievsky, 2015: 56].

Monitoring of the state youth policy revealed that volunteers could form social thought, spread political information, and make advances in public activity, for example, among students.

The extent and capacity of volunteer assistance are crucial in the time of the inability of the state to perform its organizational functions. Volunteer movement is also significant for strengthening the potential of Ukrainian society, as it demonstrated the ability of citizens to self-organization. The volunteer movement is a demonstrative positive example of Ukrainian community of the conscious personal responsibility and joint actions. The mental archetype of the Ukrainian "my home is on edge" received a value opposition in the definition of the strategy of individual behaviour. 
Volunteer movement makeshift of socio-economic realities as a factor of the conflict potential of identities enhancing in Ukraine; prevention of destructive religious and confessional influences; the creation of mechanisms for the consolidation of the nation in the context of changes in the configuration of the ethnonational "identification matrix" of the Ukrainian citizens; and concentration of the country [Volunteer, 2016: 56].

The line between these value systems and the democratic values of the modern world passes through the Maidan of 2014 as a line of a struggle between them that rooted in the consciousness of the dominant part of the Ukrainian society.

Political changes with significant results of value influence determine value priorities and form requests for their replacements. Among the value priorities of the post-Maidan period is social justice and the responsibility of the government to society. That proves the relevance of the value inquiries that led to the Revolution of Dignity, which was, above all, a revolution of values. The significance is not attributed to a political, national/ethnic, civil, regional, religious or language confrontation, but a value-ideological conflict, primarily between the society and representatives of its political structures.

The volunteer movement has the potential to articulate society-consolidating strategies, establish a new regulatory, social order that would base on justice, freedom of responsibility, solidarity and human dignity.

The role of the volunteer movement is determined as a tool for levelling the identification differences of the Ukrainian nation.

O. Zorych believes that the expectations of a "just social order" immediately after the Revolution of Dignity are unwarranted social expectations. After all, the effect of unfair expectations worked. Moral authorities of the community, volunteers articulate for the electorate the need to participate, to tune in to constant involvement in political life, readiness to control the actions of the authorities and protect the people. An effective mechanism for the introduction of values is the availability of a model for inheritance, demonstrative practices of supporting the norm, especially a certain measure of sacrifice. These practices were quite active when demonstrated by representatives of power structures and the political elite. Under such conditions, value orientations can come out of practical implementation, that is, become a public rule-making basis [Disagreements, 2015: 87].

The volunteer movement also became the subject of the popularization of the symbolic dimensions of Ukrainians. In 2014, community activists in various localities held numerous pro-Ukrainian events that were devoted to national clothing (parades of embroidered shirts), national flag (motor races, hanging flags on the balconies of houses, repainting the colours of the national flag of bridges and other elements of urban infrastructure), ideas of national unity and inviolability of the borders of Ukraine (flash mob "Map of Ukraine," which hit the national Book of Records), direct financial assistance through SMS-philanthropist ness In social networks, in particular, another special flash mob was announced: residents of the Crimea, Slavyansk, and others, the East Bridge of Ukraine photographed their passports with the words "Save the people of Donbass" or "Crimea is Ukraine" [Tymoshenko, 2014: 19].

The volunteer movement reacted to the manifestations of Ukrainophobic propaganda. The events contain entirely constructive, nation-forming ideas for cultivating patriotic feelings and belonging to the community of a single state.

Social organizations reform-oriented volunteer will play a role in harmonizing the identification differences of the Ukrainian nation, for example, the Public Lustration Committee (2014), aimed at banning compromised former public servants for a particular 
time or permanently holding public office. A tool that will provide an opportunity to prevent illegal appointments and ensure the gradual purification of state institutions from the cadres of the former criminal regime is to provide the public with open information about people who do not have the right to work on public buildings [Tomash, 2012: 366].

Patriotic volunteer public organizations carried out calls for solidarization of society based on pacifism and humanism: a peaceful Donbass — a united Ukraine - a civil dialogue. In March 2014, volunteer initiative groups of Donbass announced the formation of the Coordination Committee of the Donbas Patriotic Forces.

Initiatives of human rights volunteer social organizations assisted the population who were forced to live under the pressure of permanent political propaganda and oppression. So, in particular, the public organization "Regional Center for Human Rights" (2013) together with the "Center for Civil Liberties" (2009), "Center for Information from Human Rights" (2012), "Ukrainian Helsinki Union for Human Rights" (2009), The Center for Civic Education "Almenda" (2011) carried out work on collecting facts of violation of international law in connection with the temporary occupation of the territory of the Autonomous Republic of Crimea and the city of Sevastopol, in particular, civil rights and freedoms, starting from evil 2014. Based on empirical data numerous offenders Crimea received the title "Fear Peninsula" from activists of organizations and drew public attention to the system of political pressure and persecution of various forms of independent civil society in Crimea.

Public organizations at the national level defined the tasks of strengthening control over the three branches of government. Thus, one of the leaders of the civic organization Avtomaidan (2014), Sergy Koba, said: "Let every new official realize that he is going to work in the government for national interests, and not for his own business. Business - separately, power - separately. We will be watching this" [Public lustration committee, 2010: 4].

The idea of control acquires a starter effect. The stirrup of accountability from public authorities, citizens, forget about the need for similar transparency and non-involvement in the rights of the public with the most public organizations. As a result, as evidenced by research by GFK Ukraine in 2014, over 50\% of Ukrainians support the thesis that it is the well-off people who must pay for public initiatives from their financial assets. Over 30\% of respondents believe that business structures should deal with this and only then the Ukrainian government [Tysyachnyuk, 2010, 12].

Public organizations in the collective perception of the Ukrainian nation are often nurtured with other forms of public work. For example, in 2014, Ukrainians included the R. Akhmetov Foundation (not a civic organization, but a charitable institution), SOS Euromaidan (it is not a public organization, but a self-organized group of human rights activists and activists). So for the Ukrainian society, there is a need to introduce high-quality and large-scale civic education programs, which will assist in the expansion of knowledge about public organizations and their social mission as an essential institution in the system of political representation.

Nevertheless, the trend towards increasing social responsibility and solidarity is determined. Public organizations as generators of the principal directions of the context of open dialogue at the national level acquire a vital role in the search for the foundations of social solidarity, harmonization, and humanization of the identification differences of the Ukrainian nation.

Speculative populist technologies based on the exacerbation of cultural, ethnic and foreign policy identification differences of the Ukrainian nation, which provoked the polarization of Ukrainian society, at this stage of development of the political system acquired a new content while maintaining the overall strategy of policy implementation: in public discourse of the 
country, civic organizations and political parties emphasize attention to the need to preserve peace and consolidate the Ukrainian nation.

The functioning of voluntary public organizations is determined by contradictory ideological models of the country's development. The plantings and the systematic reproduction in the rhetoric of leaders and activists of civic organizations of the semiotic couple "your" — "Alien" formed a stereotype regarding the division of Ukrainians according to a regional principle with incompatible values. This political technology has been and remains an essential resource for mobilizing the electorate and ensuring accountability.

The objectives of public organizations in the patriotic direction in Ukraine are lustration, peace, control over the branches of government, protection of human rights and democratic freedoms, the popularization of the results of their activity and the corresponding effect, expansion of the influence of public organizations on political decision-making in government bodies. These priorities are essential for harmonization of identification differences of the Ukrainian nation and the formation of value dimensions of local self-determination of Ukrainian society as a community of one state, and it is a resource for restoring public confidence in institutionalized forms of collective life [Tyshkun, 2008: 9].

The consolidating potential of public organizations in the development of the country requires further conversion of the quantitative parameter of their work into a qualitatively new format of social representation, which will represent Ukrainian citizens, not on the basis of searching for inter-regional differences in economic, political, cultural dimensions, but on the basis of establishing the unity of the Ukrainian people in diversity and the diversity of its culture and history [Teleshun, 2010: 28].

Propaganda provocations of anti-Ukrainian content led to confidence in the volunteer movement, which became the leader among the anti-Ukrainian information warfare agents, formed a capable network of social interaction on the foundations of charity. At the same time, the volunteer movement was a manifestation of the activities and cohesion of civil society. Contrary to all the tragedy, conflict and controversy, the events in the Donbas helped to accelerate the formation of the Ukrainian political nation and the cohesion of society around the idea of developing an independent state.

It is important to find "civilian simulacra, "pocket" structures that undermine public confidence in public organizations and paralyze public activity on a national scale, provoking Ukrainian citizens to implement niche forms of civic action, namely spontaneous associations in volunteer groups.

Civic culture of volunteering is an essential resource for restoring public trust and consolidating modern Ukrainian society, which can contribute to the harmonization of relations between authorities and the public, if the state provides favourable and transparent conditions for their development and bilateral cooperation for the sake of establishing social peace in Ukraine, debugging interregional dialogue, turning away the threats of separatism.

In addition to political, there are economic aspects of the patriotic movement. Government services are trying to transfer part of the government burden onto the shoulders of civil society in the face of volunteers. Ukraine is not such a rich country to allow itself to spend more on the war than it consumes. Government officials have a noticeable desire to "save" on benefits to servicemen, so they shift them to volunteers [Improvements in the legal, 2011: 28].

Can be considered the year 2014 of birth of Ukrainian volunteering. December 5, the whole world celebrates International Volunteer Day. International Volunteer Day in the name of economic and social development established by the decision of the $40^{\text {th }}$ session of the UN 
General Assembly on December 17, 1985, to recognize the vital role of voluntary and other organizations in the social and economic development of society. The Secretary of the National Security and Defence Council of Ukraine O. Turchynov, in his greeting in 2016, pointed out that "the values of the volunteer movement, which acquired a record scale in Ukraine over the past three years and became the foundation of civil society, cannot be overestimated."

Virtual volunteering (online volunteering, cyber volunteering, digital volunteering, e-volunteering) is a type of volunteering that is performed remotely using the Internet [State, 2011: 28].

Virtual volunteering involves various activities that are performed remotely using a computer or other device connected to the Internet, such as: research projects (including wiki projects), collecting financial and non-financial sources for a specific purpose, developing software and fixing problems, creating web pages, updating web pages, maintaining profiles on social networks, writing and editing sentences, press releases, news articles, creating databases, advising on legal, business, medical issues, moderating forums, public journalism, video editing, news monitoring, answers to questions [What, 2009: 19].

In developing countries, volunteering is usually done not through the Internet, but mobile radio. Approximately $26 \%$ of people around the world had access to the Internet according to 2009 data. However, the Internet penetration rate in low-income countries was only $18 \%$, while in developed countries it was $64 \%$. Although the prices for broadband Internet are declining, many still cannot afford to have permanent access to the Internet. International Telecommunication Union (ITU). (2010). Measuring the information society. Geneva, Switzerland: ITU.

Despite these statistics, virtual volunteering is developing quite fast. Online volunteers are "people who use their time and skills for the benefit of society for free and without compensation." Virtual volunteering is not tied to a specific time or place, which means that the flexibility and freedom of volunteers and the number of opportunities to contribute significantly increases.

Online micro volunteering is another example of virtual volunteering and crowdsourcing when volunteers perform tasks on their PDAs or smartphones. To achieve such functions, nonprofit organizations do not carry out an exceptional selection of volunteers and do not conduct training. In other cases, the selection and training may be carried out in advance, and the volunteer has permission to perform a micro-task, depending on his capabilities and interest. Initially, online micro volunteering was called "byte volunteering" (byte-sized volunteering). One of the first examples of microwaving and crowdsourcing is ClickWorkers, a small NASA project that was launched in 2001. Online volunteers were offered tasks from the field of science for which fulfilment did not require scientific knowledge, but common sense: for example, to determine the presence of craters on Mars on published photos. Volunteers have not been selected or pre-trained. The authorship of the term "micro-volunteering" is usually attributed to The Extraordinaries, a non-profit organization from San Francisco. Today, thousands of non-profit organizations and other projects collaborate with online volunteers: Cravens, Jayne (Spring 2007). "Online Volunteering Enters Middle Age — And Changes Management Paradigms.” Nonprofit Quarterly (Boston: Nonprofit Quarterly).

No organization collects statistics about the best projects of virtual volunteering in the United States or the world, about how many people engage in virtual volunteering or how many organizations use online volunteers. Volunteering research rarely includes information about virtual volunteering. 
The UN has a virtual volunteer service, which used to be part of NetAid, a joint project of the United Nations Development Program and Cisco Systems to combat poverty. The Online Volunteering service, which since its inception has been under the leadership of the United Nations Volunteers program, was one of many initiatives by NetAid. She began her work in 2000 and immediately attracted thousands of volunteers. After three years of existence on the NetAid website, in February 2004.

This service, which links organizations in developing countries with online volunteers, has statistics on how many volunteers and organizations collaborate online thanks to this program. In 2013, all 17,370 tasks proposed through the Online Volunteering Service attracted a large number of applications from qualified volunteers. About $58 \%$ of 11037 online volunteers were women, and $60 \%$ were from developing countries, with an average age of 30 years. In 2013, more than $94 \%$ of organizations and online volunteers.

They appreciated the cooperation as "good" and "excellent" [About, 2011].

Organizations associated with virtual volunteering do not use this term or the words "online volunteers" on their websites and in print media. For example, the non-profit organization Business Council for Peace (Bpeace) is looking for businessmen who are willing to donate their time to train and advise entrepreneurs in countries affected by conflict, such as Afghanistan; however, the majority of these volunteers interact with Bpeace employees and entrepreneurs only online, not personally, and the term "virtual volunteering" is not mentioned on the organization's website. Bpeace is also engaged in microfonternity: the organization requests information from its supporters, for example, on the online communities of certain experts in the US, but it does not use the term "microfollowering." Another example is the Electronic Emissary, one of the first online tutoring programs launched in 1992. They do not use the words "virtual volunteering" on their website, preferring to call online volunteers "online experts."

The development of forms of volunteering will help increase volunteering opportunities. The proliferation of technology brings together more and more rural and remote areas. Nongovernmental organizations and governments are beginning to realize the value of international volunteering among developing countries and allocate funds for this. Corporations respond to the "social market" by supporting CSR initiatives that include volunteering. New opportunities for volunteering lead to the fact that more and more people become volunteers, and those who are already involved can expand their commitments.

In Ukraine, virtual volunteering is rather poorly developed. Separate virtual volunteering campaigns characterize Ukraine. One of the clearest examples of such a campaign is "Help," where you can track cases of deforestation and forest pollution, abuse of the environment. Also, in recent years, the popular platform for creating petitions. Among the particularly significant and successful appeals, one can single out the case when they demanded and achieved from the Ministry of Education and Science to make public the procedures for evaluating the effectiveness of universities.

There is another side to the concept Volunteer (fr. Volontaire, Latin. Voluntarius) - a person who voluntarily entered military service [Volunteer, 1890-1907]. In this case, you will be able to. Usually, criminal punishment threatened. However, there were not several countries, and there was not such a situation. Criminal liability for this kind of volunteering is Belarus. In April 2016, the criminal code of the Republic of Belarus included: "For this, but rather mild punishment is a restriction of 5 years." Great Britain. UK law provides legal assistance. 
The network structure of interaction with volunteer fundraising. Volunteer fundraising (eng. friendraising, peer to peer fundraising) is a fundraising strategy that uses the networks and connections of existing supporters of an organization to raise funds. The critical difference between volunteer fundraising and traditional fundraising options is that the organizing NGO acts not as a fundraising subject, but as a coordinator for the community of volunteers, each of whom becomes a fundraiser and already independently attracts funds for the company from his friends, acquaintances, and colleagues. In turn, people donate funds not because they are imbued with the mission and values of the organization that will receive their donations, but because a friend asked them to do so. Classic examples of volunteer fundraising in the world include Movember, ALS Ice Bucket Challenge (related to the so-called Challenges), Sleepout, and Race for life.

The idea of volunteer fundraising is structured by network marketing - money for the implementation of any projects and programs is requested not by the organization itself, but by its representative: a volunteer trained and instructed in advance [Yurchenko, 2009: 4]. He asks for money for financing projects not from strangers and first comers, but from his friends, relatives, and colleagues with whom he has established a trusting relationship. To attract attention to fundraising, volunteers participate in various kinds of actions, which, more often, imply some "overcoming." The distinction of volunteer fundraising from the classic options for raising funds is the organization and the pyramidal structure of the process. While in fundraising, a non-profit organization itself acts as a fundraiser for each specific donor, in volunteer fundraising, NGOs operate only as an organizer of a community of volunteers, each of whom becomes a fundraiser and attracts funds from his friends, acquaintances, and colleagues. Volunteer fundraising increases the involvement of already existing supporters of a charitable organization and helps to attract new donors to its support [Stepanenko, 2016: 14].

Forio volunteer fundraising in which volunteers independently organize events or activities to collect charitable donations is Do-it-yourself (Do-it-yourself - do it yourself): for example, a concert, all the proceeds from which go to charity. A non-profit organization may help with donating or donating resources for organizing an event, but the fundraising campaign itself and donation activities must be initiated and organized independently by a supporter [Zhuzha, 2016: 12]. The strategy can be useful, as for many DIY charity organizations, fundraising provides an opportunity to spur the energy of supporters who want to do a little more than donate money, namely, to express their appreciation and support to the charity by bringing their friends, family members and colleagues.

\section{Conclusions}

The political trends in the development of modern societies are marked by an increase in the private dimension of citizens' lives. In the Ukrainian reality, the dynamics of increasing the involvement of citizens to the volunteer movement, in our opinion, has become a fact for the prospects of forming horizontal ties of civil society. A model of state-society relations in the field of volunteering as a benchmark of their optimization in Ukraine. It consists of four sheets: functional; organizational; administrative and political; and ideological.

Prospects for further research. It is essential to study the strategies of the volunteer movement, the prediction of components to ensure the strategic positions of the social change. 


\section{[ㅁ] References}

About the UNV Online Volunteering service, 2011. Statistics:https://onlinevolunteering.org/en/ org/about/statistics.html.

Disagreements of identity in Ukraine and the ways of their regulation in the context of the policy of civil consolidation of the Ukrainian nation. Similar to the report. Kyiv: Ipiend im. I.F. Kuras, National Academy of Sciences of Ukraine, 2015.

Golub, Viacheslav L. Volunteering in the system of the state-society relations. Manuscript. Thesis for obtaining the candidate of sciences degree in public administration; specialty 25.00.01 — theory and history of public administration. National Academy for Public Administration under the President of Ukraine, Kyiv, 2016: 17.

Improvements in the legal and regulatory framework for civil society organizations in the context of the signing of the Association Agreement. 01/10/2016: http://www.niss.gov. ua/articles/1702/2/5.

Kornievsky, Oleksander. Volunteer movement: world experience and Ukrainian civil practices. Kyiv: NISS, 2015.

Public lustration committee, 2010. http://lku.org.ua/.

Stepanenko, Victor P. Civil society: discourses and practices. Monograph. The dissertation is presented for the Doctor's Degree in sociology. Specialisation: 22.00.01. Institute of Sociology, National Academy of Sciences of Ukraine, Kyiv, 2016: 24.

State of the World's Volunteerism Report 2011: Universal Values for Global Well-Being, United Nations Volunteers, 2011.

Teleshun, Yaroslav. Formations and development of the foundations of civil society in the conditions of the $21^{\text {st }}$ century: the political and legal aspect of Ukrainian realities. Tribune: All-Ukrainian socio-political and theoretical journal Comrade Knowledge of Ukraine and the Union journalists of Ukraine. No 9/10, 11/12, 2010: 56-57.

Tomash, Leonid V. Civil society as a life support system in the political, economic, social and spiritual spheres. Journal of Kiev University of Law: Ukrainian scientific-theoretical journal, No 2, 2012: 366-371.

Tymoshenko, Nadiia. On the issue of the functioning of public organizations, 2014. http://icp. org.ua/aspekt/aspekty/susp/2004/10/08/do_pitannja_funktsio_23.html.

Tyshkun, Yuri Y. Institutions of the civil society in Ukraine as a factor of rationalization of the state bureaucracy [Text]: dis. Cand. watered Sciences: 23.00.02. Nat. University "Lviv. Polytechnic" In-t of humanity and soc. sciences, 2008.

Tysyachnyuk, M. Thousands of MS New approaches to the analysis of cross-border social movements in the context of globalization. Journal of Sociology and Social Anthropology. No 3, 2010: 38-62.

UN Online Volunteering Service moved to its own domain. UNV Online Volunteering service, History: https://onlinevolunteering.org/en/org/about/history.html.

Voluntary work. European Parliament Special Eurobarometer 75.2. Brussels, 27 June 2011.

Volunteer movement in Ukraine, 2016. http://www.gfk.com/ua/documents/presentations/ report_vyshlisky.pdf.

Volunteer. Encyclopedic Dictionary of Brockhaus and Efron: in 86 tons (82 tons and 4 add.). SPb., 1890-1907.

What are examples of virtual volunteering? Archive dated July 1, 2009 on the Wayback Machine. AIDSvolunteers.ca. Retrieved 5 October 2009. 
Yurchenko, Iryna. The Institutionalization of the Volunteer's Movement in Ukraine. Manuscript. Thesis for the degree of candidate of sociological sciences by specialty 22.00.03 - Social Structures and Social Relations. Institute of Sociology of National Academy of Sciences of Ukraine. Kyiv, 2009: 18.

Zhuzha, Lilia. Volunteerism in the context of the Antiterrorist operation in Ukraine: political dimension. As a manuscript. The thesis for obtaining a scientific degree of Ph.D. (Candydate of science) in Political Sciences. G.S.Skovoroda Kharkiv National Pedagogical University, Kharkiv, 2016. 